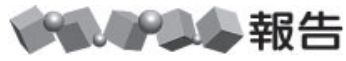

Technical Report

\section{田中貴金属工業 ( 株 ) における貴金属回収*}

\title{
Recycling of Precious Metals at Tanaka Kikinzoku Kogyo K.K.
}

\author{
by Akihiko OKUDA ${ }^{\mathrm{a}}$
}

a. Tanaka Kikinzoku Kogyo K.K.,Hiratsuka, Kanagawa 254-0021

(Corresponding author E-mail: okuda@ml.tanaka.co.jp)

Tanaka Kikinzoku Kogyo K. K. is refining and recovering the precious metals ( $\mathrm{Au}, \mathrm{Ag}$, and six platinum group metal elements) and manufacturing their products. In this report, typical recycling processes for the precious metals from used electronic device, plating and deposition jigs, and the scrap containing platinum group metals such as automobile catalysts are described. These processes consist of the accurate evaluation, acid or cyanate dissolution, separation by precipitation, cementation, solvent extraction, or ion exchange, and recovery by electrowinning or chemical reduction.

KEY WORDS: Tanaka Kikinzoku Kogyo, Precious Metals, Platinum Group Metals, Recycling, Recovery, Refining

\section{1.は じめに}

田中貴金属工業株式会社は, 1885 年に創業し, およそ 120 年 間国内外において貴金属の製品の供給とともに貴金属のリサイク リング業を営んできた。創業当時より白金工業製品の製造を手掛 け，各種工業製品の国産化，オスミリジウム精錬の国産化技術の 確立 ${ }^{1)}$ 等古くから白金族金属をはじめとする貴金属の製品化お よび精錬について取り組んできた。現在では時代の変遷にもとも ない $\mathrm{Au}, \mathrm{Ag}$ および白金族金属 6 元素を加えた貴金属の製品の製 造と貴金属の一貫した回収精製を行っている。

貴金属の利用分野は，多岐に渡っており，すべての分野で必ず ぞこかで用いられているといっても過言ではない。なかでも $\mathrm{Au}$, $\mathrm{Ag}$ は電気的, 機械的特性に優れていることから電気, 電子材料 に多く用いられている。また, 白金族金属は, 耐酸化性, 触媒活 性, 生化学的活性, 電磁的特性に特異な性質を有していることか ら，近年では制ガン剤としてのPt 化合物の利用，ハードディス クの磁気材料としての Pt， Ru 材の採用等従来では知り得なかっ た新しい分野にも貴金属が用いられている。

一方で貴金属は高価であるため，使用量を削減するように構造 や工法が工夫される。また, より安価な貴金属への転換や合金の 導入による使用量の削減とともに, 脱貴金属の転換が計られる運 命にある。しかしながら, 新規の貴金属利用分野が常に開拓され， その用途拡大は留まることを知らない。

このようななか，弊社では，「エネルギー」、「環境」、「リサイ クル」,「バイオ」の 4 つの分野を基軸とした事業展開を図ってい

*2007 年 7 月 31 日受付 9 月 22 日受理

1. 普通会員工博 田中貴金属工業 (株) 湘南工場

[ 著者連絡先] FAX：0463-22-4344( 田中貴金属工業 湘南工場 ) E-mail : okuda@ml.tanaka.co.jp

キーワード：田中貴金属工業(株), 貴金属, 白金族金属, リサイクル, 回収, 精製
る。貴金属材料や貴金属製品を提供した場合, 加工に伴うスクラッ プや使用済みの回収物が必ず発生する。これらのものから貴金属 を回収, 精製し, 再生した貴金属材料を提供するというリサイク リングは，資源の循環，環境の調和との観点からさらに重要な位 置付けにあるものと考える。

以上のようなことを鑑みて, 田中貴金属工業 (株) におけるリ サイクリングの取り組みと回収精製技術の概要を説明する。

\section{2. 貴金属の回収技術 2)}

\section{$2 \cdot 1$ 貴金属リサイクリングの対象物}

田中貴金属工業株式会社での事業内容は電気・電子材料の製造 を中心としたメーカである。宝飾品や地金の製造販売業務での知 名度は高いが, 近年ではメディカル分野への参入も行い, 多岐に わたる分野への展開を図っている。このように貴金属の取扱いの 適用範囲は広く, さまざまな分野からのスクラップの発生がとも ない,これらは全て貴金属の回収物の対象と成りうるものである。

回収物を大別すると, 製造プロセスで発生するプロダクツスク ラップと製品が一度市場に出回ったものから回収寸る使用済製 品からの貴金属回収とがある。前者は, 回収物の履歴が分かり, 比較的分別されやすいことから, 貴金属を使用しているメーカで は, 何らかの方法で貴金属の回収を行っている。一方で, 後者の 回収物は製品として出回ったものであり，貴金属の回収を効率よ く行うために解体と分別が行われる。たとえば携帯電話や自動車 の排ガス浄化用の廃触媒からの貴金属の回収が該当する。

貴金属を含有するものが，商業的に回収物の対象になるかどう かは，そこから回収される貴金属含有量と貴金属の地金価格が， 回収コストに見合うかどうかによって評価される。これらは，さ まざまな要因によって左右される。たとえば回収コストは，貴金 属含有量や回収物の形態や回収し易さによって変動する。また, 地金の価格によっても大きく変わる。一例では, Ruの地金価格 


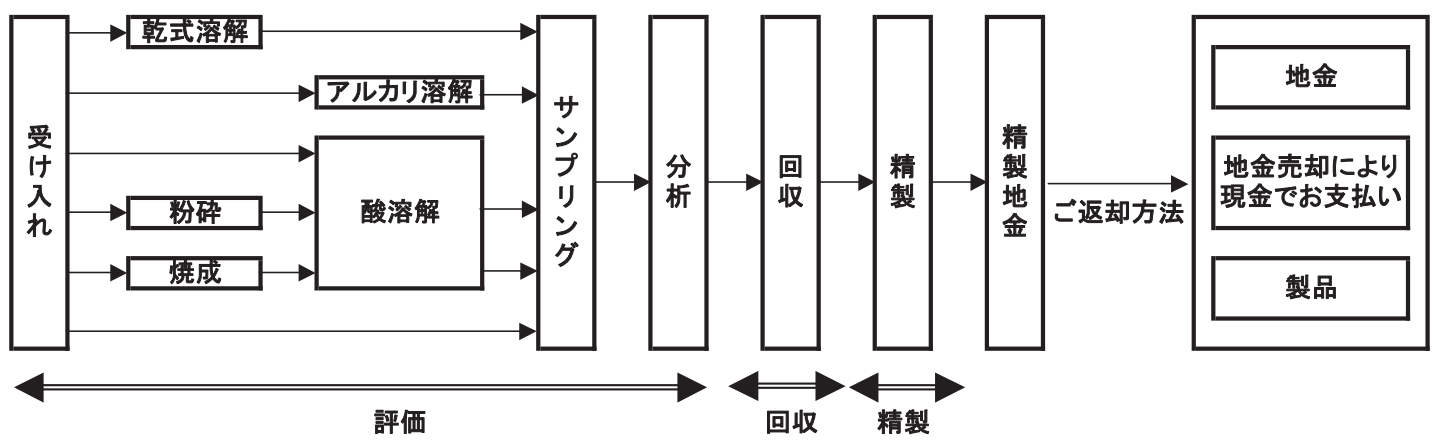

Fig.1 Flow sheet from the acceptance of the precious metal scrap to the shipment.

が 2007 年前半において急騰し, 数年前に比べて数倍から十倍以 上の価格の変動が生じた。Ru は回収精製コストが，他の貴金属 よりかさむ場合が多く，回収精製するよりも新規に Ru 地金を購 入した方が安価な場合もあった。しかしながら，現状 Ru の価格 が高価であるため Ru を回収しても採算が合うことから回収物の 対象となっているものも多い。

\section{$2 \cdot 2$ 貴金属の回収精製の流れ}

Fig. 1 亿貴金属の受け入れから出荷までのフローを示す。大き な流れとして, 評価, 回収, 精製との工程からなる。評価とは, 回収物に含まれる貴金属の含有量を決定することにある。これら は，母体より偏りのない分析サンプルを取る必要があることから 前処理を行うことが多い。この前処理とは, ウエスやフィルター 等の減容化, 溶解を容易にするための焼成, 半導体部品やモール ドされた電子部品等から貴金属を抽出しやすくするための粉砕な どをいう。また，異種金属が一つの回収物の中に偏在，あるいは 他種類の貴金属を含む金属が混合して，均一なサンプリングが困 難な場合, あるいは酸化物成分やセラミック成分が混在する場合, 銅など地金を加えて母体を均一化させるために合金化を行うこと も多い。いずれの場合も，評価における前処理は，均一なサンプ リングを行い, 正確な地金評価を行うための大切な手段であると している。

田中貴金属工業 (株)の場合, サンプリング後分析結果を報告 し, 依頼者より地金含有量の決裁を戴くまで, 回収される貴金属 は預かり品となる。決裁後は, 回収した地金を返却あるいは地金 を売却して現金で決済するか, お預かりした貴金属地金を用いて, 化合物やめっき液あるいはペースト，ターゲット等製品として返 却する方法も用意されている (製品に加工寸る費用は回収した地 金の価格と相殺することも可能である)。

\section{$2 \cdot 3$ 貴金属の溶解}

貴金属の分離回収を行うにあたり，多くの場合湿式工程を経た のち精製を行う。溶液化の方法は, 塩酸や硝酸の鉱酸あるいはシ アン化アルカリによる溶解が用いられる。Auを溶かす代表的な 溶解液として王水がある。王水の組成は一硝三塩と呼ばれ, 硝酸 1 に対して塩酸 3 との混合物として知られているが，実際には式 (1) で示されるように, 硝酸 1 塩酸 4 の割合で混合した混酸で溶 解することが多い。また, $\mathrm{Au}, \mathrm{Pt}, \mathrm{Pd}$ の溶解では王水を用いず, 式 (2)のように塩酸一塩素による溶解も行われる。

$$
\begin{aligned}
& \mathrm{Au}+\mathrm{HNO}_{3}+4 \mathrm{HCl} \rightarrow \mathrm{HAuCl}_{4}+\mathrm{NO}+2 \mathrm{H}_{2} \mathrm{O} \\
& 2 \mathrm{Au}+2 \mathrm{HCl}+3 \mathrm{Cl}_{2} \rightarrow 2 \mathrm{HAuCl}_{4}
\end{aligned}
$$

この方法は, 王水より溶解力が劣るが, 硝酸根を取り除く操作 $($ 脱 硝という) が不要であるため溶解方法に用いられることも多い。 硝酸根や亜硝酸根が溶存している王水中に白金族金属が含まれる
Table 1 Typical methods of separation, recovery and refining for precious metals.

\begin{tabular}{c|ccc}
\hline & 回収 & 分離 & 精製 \\
\hline 沈殿析出 & $\bigcirc$ & $\bigcirc$ & $\bigcirc$ \\
電解析出 & $\bigcirc$ & $\bigcirc$ & $\bigcirc$ \\
セメンテーション & 0 & $\bigcirc$ & \\
イオン交換樹脂を用いた処理 & 0 & $\bigcirc$ & $\bigcirc$ \\
活性炭による吸着 & 0 & & \\
溶媒抽出法 & & 0 & $\bigcirc$ \\
酸化蒸留 & & 0 & 0 \\
\hline
\end{tabular}

と, 白金族金属イオンがニトロシル錯体やニトロ錯体を形成する。 これらの錯体は沈殿生成, イオン交換反応や溶媒抽出反応に支障 を来す場合があることから, 塩酸一塩素による溶解が用いられる。

酸による溶解方法では貴金属だけでなく他の金属も溶解するこ とから, 貴金属だけを選択に溶解する手法も用いられる。例えば, $\mathrm{Cu}$ や $\mathrm{Ni}$ 上に $\mathrm{Au}$ や $\mathrm{Ag}$ がめっきあるいは蒸着されたものであれば, 式 (3), (4) のようなシアン化ナトリウムによる溶解により $\mathrm{Au}$, $\mathrm{Ag}$ のみが選択的に溶解できる。この方法では $\mathrm{Cu}$ や $\mathrm{Ni}$ などの台 材がそのまま残存することから， $\mathrm{Au} ， \mathrm{Ag}$ の選択溶解とともに台 材が有価物として再利用できる。同様にステンレス材は硝酸に耐 食性を有することから, 式 (5) のように $\mathrm{Ag}$ や Pd のみを選択的に 溶解する硝酸が用いられる。貴金属のみを選択的に溶解する方法 は，スパッタリングやめっき等で治具やマスクに付着した貴金属 の回収に適用している。

$$
\begin{aligned}
& 2 \mathrm{Au}+4 \mathrm{NaCN}+\mathrm{H}_{2} \mathrm{O}_{2} \rightarrow 2 \mathrm{NaAu}(\mathrm{CN})_{2}+2 \mathrm{NaOH} \\
& 2 \mathrm{Ag}+4 \mathrm{NaCN}+\mathrm{H}_{2} \mathrm{O}_{2} \rightarrow 2 \mathrm{NaAg}(\mathrm{CN})_{2}+2 \mathrm{NaOH} \\
& 3 \mathrm{Ag}+4 \mathrm{HNO}_{3} \rightarrow 3 \mathrm{AgNO}_{3}+2 \mathrm{H}_{2} \mathrm{O}+\mathrm{NO}
\end{aligned}
$$

\section{$2 \cdot 4$ 貴金属の回収技術}

貴金属を含有する回収物は多種多様であり，画一的な方法は無 く, 形状, 形態, 処理量を鑑みた上, 含有寸る貴金属成分, 他の 金属成分を考慮し，個別に前処理方法および回収方法が決定され る。評価後, 回収された貴金属は，精製工程に移行するが，白金 族金属が含有する場合，とりわけ Rh， Ir, Ruが含まれる場合は その処理工程が複雑になる。いずれの場合も単一な処理工程を経 ることは少なく幾つかの工程が組み合わせられて回収精製が行わ れる。Table 1 は田中貴金属工業 (株) 内で用いている分離精製 の手法について一例を示したものであり, Table 2 に, 各貴金属 元素に適用される分離精製手法を示す。また，弊社では金銀が多 く含まれる回収物か, 白金族金属が多く含まれる回収物かによっ て受け入れる事業所と処理方法が異なる。 
Table 2 Typical separation and refining methods in Tanaka Kikinzoku Kogyo.

\begin{tabular}{c|l}
\hline 対象となる貴金属元素 & 適応される主な分離·精製手法 \\
\hline $\mathrm{Ag}$ & AgClによる沈殿分離、還元剂もしくは電解によりAg粉末の析出 \\
$\mathrm{Au}$ & 選択還元、溶媒抽出法による分離、精製 \\
$\mathrm{Pt}$ & 沈殿法、溶媒抽出法による分離、精製 \\
$\mathrm{Pd}$ & 沈殿法、溶媒抽出法による分離、精製 \\
$\mathrm{Rh}$ & 沈殿法、溶媒抽出法、イオン交換樹脂による分離、精製 \\
$\mathrm{Ir}$ & 沈殿法、溶媒抽出法、イオン交換樹脂による分離、精製 \\
$\mathrm{Ru}$ & 四酸化蒸留による分離精製 \\
\hline
\end{tabular}

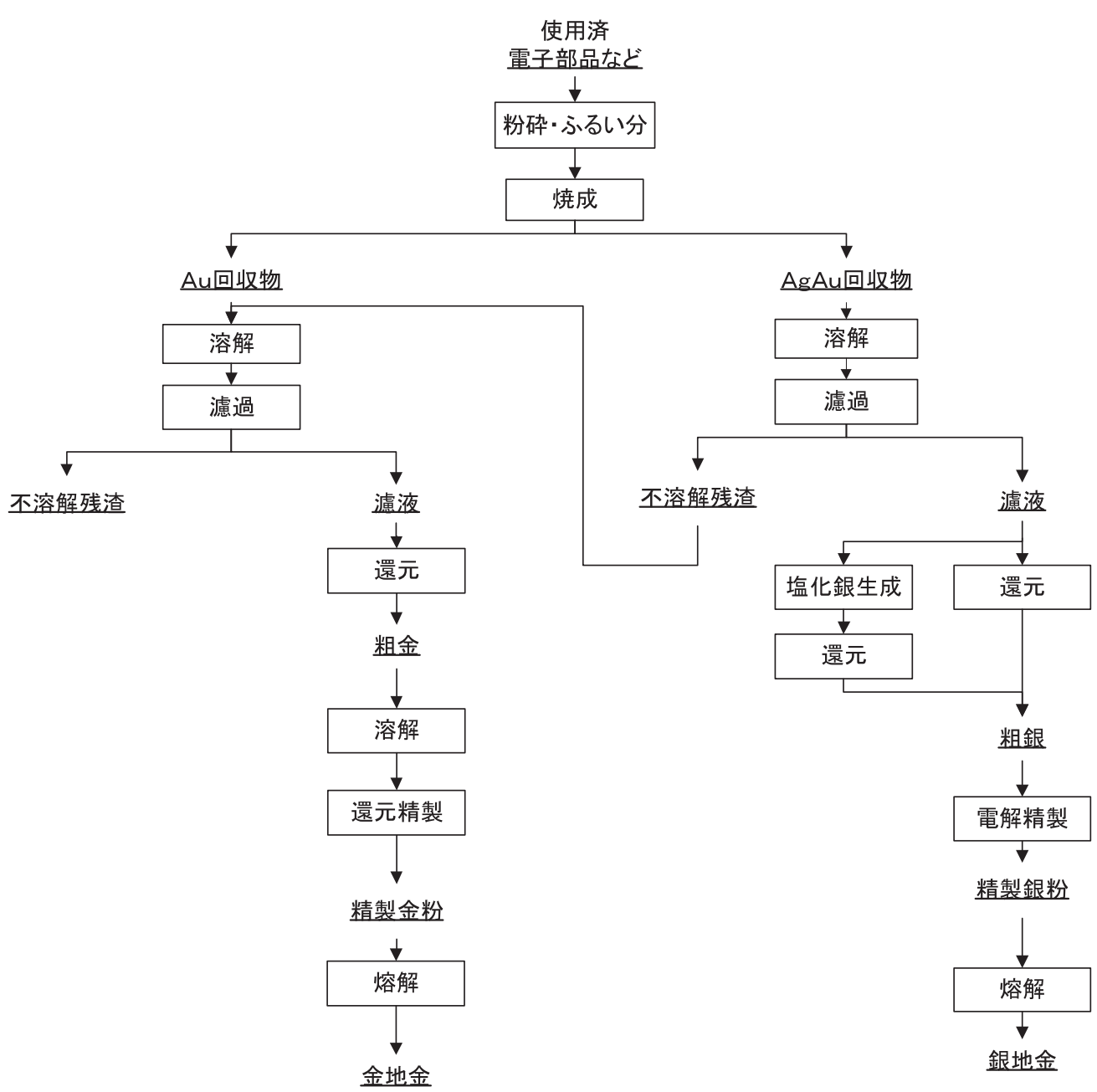

Fig.2 Recovery and refining flow of $\mathrm{Au}$ and $\mathrm{Ag}$ from used electronic device.

\section{$2 \cdot 4 \cdot 1 \mathrm{Au}, \mathrm{Ag}$ を含有する電子部品等からの回収技術}

$\mathrm{Au}, \mathrm{Ag}$ の回収物は $\mathrm{Au}$ と $\mathrm{Ag}$ の混合比により手順は異なる。 $\mathrm{Ag}$ が多く含まれるものは，硝酸溶解後湿式による還元もしくは $\mathrm{AgCl}$ で沈殿分離し, 還元後電解精製もしくは湿式法により精製 を行う。 $\mathrm{Au}$ が多く含まれるものについては, 王水溶解後ろ液を 湿式還元 (粗金回収) し, 粗金より湿式精製 (4N : 99.99\%) を行っ て，精製金粉を得る。回収精製のフローを Fig. 2 に示す。

$2 \cdot 4 \cdot 2$ めっきあるいは蒸着された治具からの $\mathrm{Au}, \mathrm{Ag}$ 回収 $\mathrm{Au}, \mathrm{Ag}$ が薄い皮膜として台材に存在しているものには，シア ン化アルカリに酸化剤を加えた溶液を用いることで, 表面の $\mathrm{Au}$, $\mathrm{Ag}$ を選択的に溶解し, 台材をそのまま再利用することができる。 剥離して溶解した $\mathrm{Au}, \mathrm{Ag}$ は, 式 (6), (7) に示される $\mathrm{Zn}, \mathrm{Al}$ 粉 末等の水素より卑な金属粉を加え, 金属置換をおこなって貴金属
を回収するするセメンテーションの方法が用いられる。

$$
2\left[\mathrm{Au}(\mathrm{CN})_{2}\right]^{-}+\mathrm{Zn} \leftrightharpoons\left[\mathrm{Zn}(\mathrm{CN})_{4}\right]^{2-}+2 \mathrm{Au} \downarrow
$$

$2\left[\mathrm{Ag}(\mathrm{CN})_{2}\right]^{-}+\mathrm{Zn} \leftrightharpoons\left[\mathrm{Zn}(\mathrm{CN})_{4}\right]^{2-}+2 \mathrm{Ag} \downarrow$

回収された粗金，粗銀は精製工程へと回される。この際，フリー シアンが多く溶存していると Zn 粉末が多く消費され, 非効率な 場合がある。このようなときには, 電解析出による $\mathrm{Au}, \mathrm{Ag}$ の回 収が行われる。シアン溶液中からの $\mathrm{Au}, \mathrm{Ag}$ の回収は, Ptを $\mathrm{Ti}$ 板にめっきした不溶性電極を用いて, 電解析出により行っている。 これらの電解回収装置は, リカバセル ${ }^{\circledR}$ という商品名で販売も しており, めっき廃液等からの貴金属の回収装置としても用いら れている。

蒸着治具では, 蒸着されるワークや積層構造により $\mathrm{Au}$ をはじ 


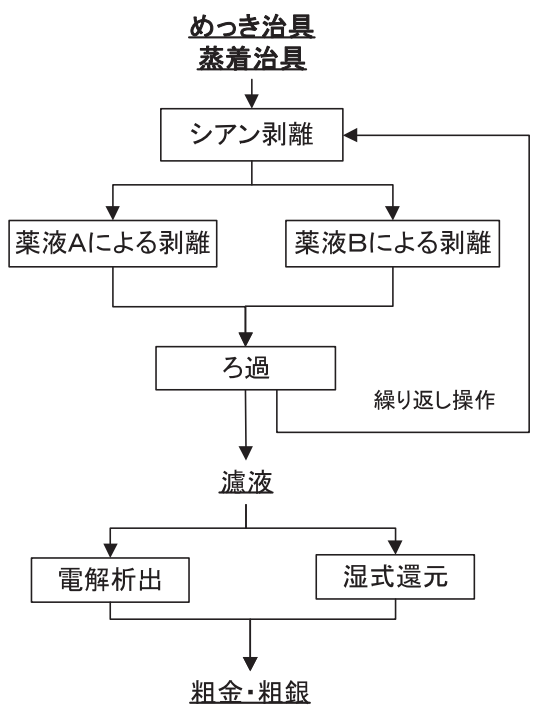

Fig.3 Recovery and refining flow from the scrap of plating and deposition jigs.

めとする各種金属が多種類に渡って積層される。この場合，積層 された金属の構成に応じて剥離の手順が決められ，構成される金 属の種類により剥離液が選定される。また，いくつかの薬液を併 用し，繰り返し行うことで積層されたものから貴金属や他の金属 を剥離し，洗浄およびクリーンルーム内で清浄化した後，ユーザ 一治具をリサイクルすることも行っている。Fig. 3 にこれらの回 収の流れの概要を示す。

$2 \cdot 4 \cdot 3$ 白金族金属を含有する回収物からのリサイクリング

Table 3 に Pt，Pd，Rh の主な用途を示す。表中に示されるよ ういずれも自動車排ガス浄化用触媒に用いられ，使用量も供給量 の大半がこれらの触媒材料に使用されている。田中貴金属工業 （株）では，使用済みの廃触媒からの白金族金属の回収を，回収 事業の一つの基軸と考え，他の石油化学関連の回収物とともに， 株式会社日本ピージーエムとの共同で回収事業を営んでいる。株 式会社日本ピージーエムでは，廃触媒から乾式製鍊により銅合金 中へ貴金属を濃縮する技術を有している。貴金属を濃縮した銅合 金からは，弊社工場内で各貴金属に分離精製される。また，銅合 金からの貴金属回収だけでなく，他の廃触媒やガラスの溶解装置 等の回収を含め，あらゆるものから白金族金属の分離精製を行っ ている。

白金族金属の分離精製法は，先に述べた Table 1, 2 での手法の 組み合わせとなる。近年では，溶媒抽出やイオン交換樹脂による 分離精製手法が基幹プロセスとなるが, 古典的な沈殿分離法も個 別に用いられている。Fig. 4 に白金族金属を含む分離精製プロセ スの概要を示す。
Table 3 Typical uses of Pt,Pd and Rh.

\begin{tabular}{c|l}
\hline $\mathrm{Pt}$ & $\begin{array}{l}\text { 自動車用排ガス浄化触媒、化学·石油化学用触媒、 } \\
\text { ガラス溶解用るつぼ·装置、白金装飾品、白金コイン・バー }\end{array}$ \\
\hline $\mathrm{Pd}$ & $\begin{array}{l}\text { 自動車用排ガス浄化触媒、装飾品、 } \\
\text { 科材料、エレクトロニクス材料 }\end{array}$ \\
\hline $\mathrm{Rh}$ & $\begin{array}{l}\text { 自動車用排ガス浄化触媒、化学·電気用材料 } \\
\text { ガラス溶解用るつぼ·装置、 }\end{array}$ \\
\hline
\end{tabular}

\section{AuAgPtPdRhIr回収物}

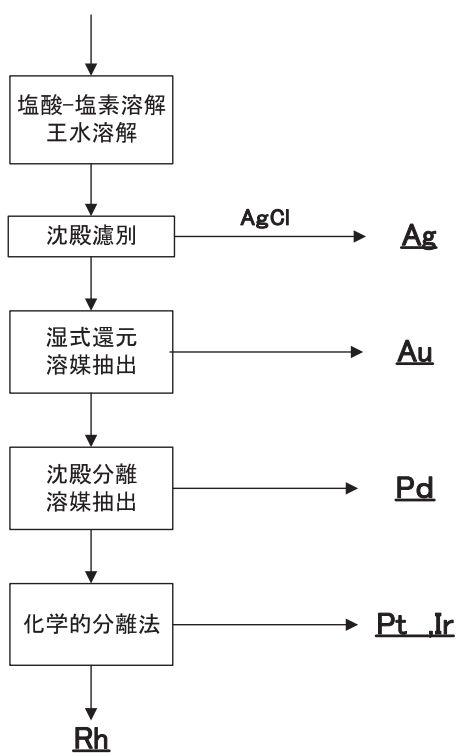

Fig.4 Typical flow of recovery and refining from the scrap of platinum group metals.

\section{3.おわりに}

貴金属の用途亡需要は今後とも拡大寸る傾向にある。従来活用 されていなかった貴金属の特性も見直され，新たな貴金属の利用 分野も見いだされている。このようななか，限られた資源を有効 活用するにはリサイクリングが不可欠となる。田中貴金属工業 （株）は，貴金属の地金や製品の供給メーカとしてだけではなく， 環境に配慮した回収精製技術を基盤に貴金属をリサイクリング し，常に革新的な技術導入を行いつつ貴金属という資源の供給に 努めたい。

\section{References}

1) S. Tanaka: Kikinzokunokagaku-Jyohen, (Tanaka Kikinzoku Kogyo), pp.107-114 2) J Shibata, A Okuda: Journal of MMU, 118(2002), 1-8. 